"Corporate governance practices in the banking sector of Bangladesh: do they really matter?"

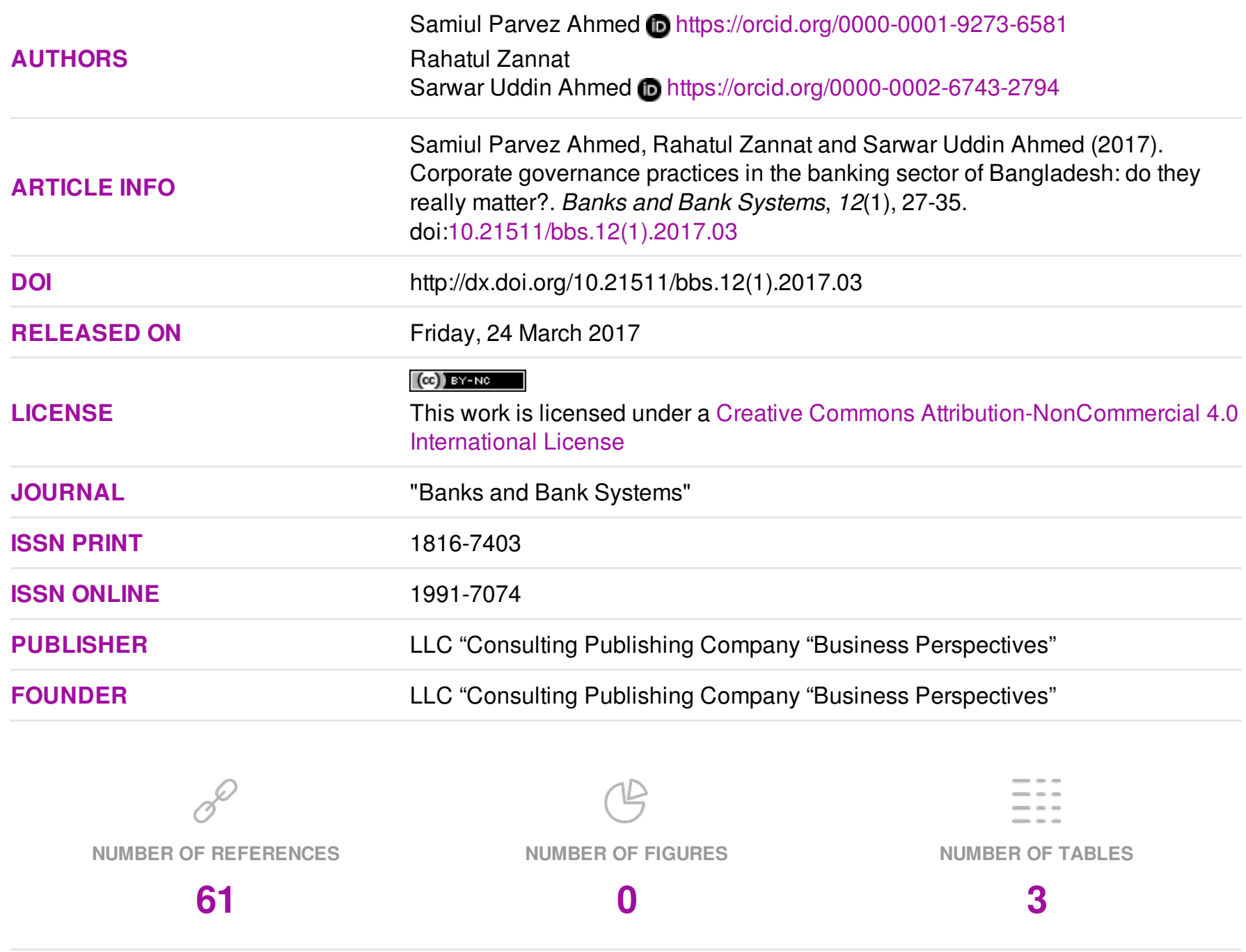

(C) The author(s) 2022. This publication is an open access article. 


\title{
Corporate governance practices in the banking sector of Bangladesh: do they really matter?
}

\begin{abstract}
A well governed institution is expected to use its resources optimally and, thus, perform more efficiently and contribute positively to economic development of a nation. However, often, it can be seen that poor management of the stakeholders leads to less than optimal strategic directions for an institution. Due to recent global financial crisis and rising issues of the Bangladeshi banking sector, corporate governance is one of the factors that have gained considerable attention. Recent drive of the governance issues of the banking sector of Bangladesh is expected to bring positive change in the financial sector and, hence, it is crucial to assess whether complying with governance codes leads to desired outcome or not. Specifically, the main purpose of this study is to examine the relationship between performances of commercial banks with corporate governance factor along with some internal and macroeconomic variables. Thus, the listed commercial banks in the Dhaka Stock Exchange (DSE) of Bangladesh were considered for the study. Subsequently, considering data availability of the time period (2011-2014), 29 listed commercial banks in the DSE have been considered and, hence, Ordinary Least Squared (OLS) regression models were used through Eviews 8.0 for analyzing the data. Though the study shows a positive relation between corporate governance and performances of banks, the statistical insignificance of the relation raises concern regarding various issues of corporate governance in the financial sector of Bangladesh.
\end{abstract}

Keywords: corporate governance, financial institutions, performances of commercial banks.

JEL Classification: G21, G30, G38, G39, O16.

\section{Introduction}

Banks play a vital role in economic development of our nation. It is noteworthy to recognize how well our financial sector is functioning. Particularly, developing economy like Bangladesh, where there is underdeveloped capital market, highly depends on the intermediary role of financial institutions for channeling funds to the deserving one in an efficient manner. Thus, researchers, academicians and policy actors put forth sincere effort to recognize the factors that influence the operations of financial institutions and, hence, contributions of the financial institutions in the economy of the country. And, among all the mainstream factors, corporate governance is one of the factors that have gained considerable attention recently due to several contemporary issues regarding governance issues of the financial sector of the nation and, hence, it has become imperative to measure the impact of it on banks' performances.

In general, it is important to have a transparent and healthy banking system for the growth and development of the economy. For this reason, this sector needs more supervision. Because of the global financial crisis, experts realized that bank needs better supervision and good governance. Sound corporate governance of

\footnotetext{
(C) Samiul Parvez Ahmed, Rahatul Zannat, Sarwar Uddin Ahmed, 2017. Samiul Parvez Ahmed, Ph.D., Assistant Professor, School of Business, Independent University, Bangladesh.

Rahatul Zannat, Student, School of Business, Independent University, Bangladesh.

Sarwar Uddin Ahmed, Ph.D., Dean and Professor, School of Business, Independent University, Bangladesh.

This is an Open Access article, distributed under the terms of the Creative Commons Attribution-NonCommercial 4.0 International license, which permits re-use, distribution, and reproduction, provided the materials aren't used for commercial purposes and the original work is properly cited
}

banks can also lower the investment risk of investors and helps to reduce the cost of financing, which will ultimately introduce a steady flow of foreign investment into the country (Farooque et al., 2007).

As mentioned earlier, nowadays many researchers are mostly concerned about the relationship between governance and performance. A good governed bank is expected to perform more efficiently. Ajanthan, Balaputhiran \& Balasundaram (2013) provide three statements why corporate governance is important for performance. They state that: "First, governance may reduce the incidence and amounts of related parties' transactions and other "self-dealing" practices. Since such transactions are usually sub-optimal from the efficiency point of view, the reduction in such transactions should translate into improved performance. Second, better governed banks may have lower cost of capital, especially if they employ subordinated debt financing. Third, better governance may translate into more efficient and streamlined operations, as the supervisory board and management functions are separated and modernized".

But, in Bangladesh, in many cases, institutions are owned and governed by same persons, who, often, belong to same family or network of keens. So the corporate governance practices in Bangladesh are little absent in many organizations. There are some components described by Ahmed and Yusuf (2005) in their study such as poor bankruptcy laws, no push from the international investor community, limited or no disclosure regarding related party transactions, weak regulatory system, weak general meeting scenario, lack of shareholder active participations are commonly persist in institutions and because of these issues, a good corporate governance is questionable in Bangladesh. But, for the economic de- 
velopment of developing country like Bangladesh, corporate governance of the financial institutions is particularly important. It is well articulated that economic development depends on well and soundly managed banking system. To achieve a wellmanaged banking system, Bangladesh Enterprise Institute (BEI) published the Code of Corporate Governance (CCG) and it is also suited for, among others, financial institutions. The main purpose of CCG is to improve the general quality of corporate governance practices in Bangladesh.

Considering these issues, this research intends to identify the impact of corporate governance, along with some other determinants, on performance of the private commercial banks in Bangladesh.

\section{Problem statement}

There are some several basic reasons for the growing interest in corporate governance. Such as, if a bank fails to practice good corporate governance or lack of effective governance within the institution, it may cause insolvency of the bank and that may result in lack of confidence in the financial system of the country, because the confidence of the people in the entire banking system is important for a proper economic development of the country. It is widely argued that effective corporate governance practices are fundamental to gain and maintain the confidence of the people on banking system (BCBS, 2006, February).

In Bangladesh, there are 64 banks of which 4 state owned commercial banks, 4 development financial institutions, 39 private commercial banks and 9 foreign commercial banks and other are some specialized banks across the country (BB, 2016). In Bangladesh, banks play a vibrant role to ensure sustainable economic growth (having more than six percent gross domestic product) in last few decades. So it is important to know which factors have great influence on financial performance of banks. There are many different ways to measure financial performance and corporate governance is one of them. Hence, the study focuses on the relationship between corporate governance of Private Commercial Banks (OCBs) of Bangladesh and its impact of their performances.

\section{Literature}

Different authors define corporate governance differently based on their own point of view. For example, Brigham \& Ehrhardt (2005) stated that corporate governance is the set of rules and procedures that ensure that managers do indeed employ the principles of value based management. There are some other statements of other authors. For example, Cadbury Report (CFACG 1992) described corporate governance as a system by which companies are directed and controlled. Another thought refers corporate governance as interrelationship of corporate direction with firm per- formance (Uchida et al., 2011); specifically, "structures and processes for decision making, accountability, control and behavior at the governing body" (Public accounts and Estimates Committee, 2002). It is also argued that corporate governance is about "finding ways" to ensure effective decision making (Pound, 1995). But there is a fundamental concern of corporate governance is that a firms directors and managers should have to be accountable to ensure good and necessary protection to shareholders. In this similar vein, Ahmed and Uchida (2009) define corporate governance as "...a mechanism by which companies are governed and/or monitored by the stakeholders: shareholders, auditors, regulators, credit agencies, and so forth". The World Bank described that corporate governance should be based on four "pillars" Responsibility, Accountability, Fairness and Transparency (RAFT). Similarly, corporate governance can be defined as the relationship among shareholders, board of directors and the top management in determining the direction and performance of the corporation (Wheelen and Hunger, 2006). Or, in other words, corporate governance mechanisms are the methods employed at the firm level to solve corporate governance problems (Basuony et al., 2014). Once the concept of corporate governance is developed, the issue comes how to measure this factor for an organization. Over time researchers and practitioners have developed a measurement tool popularly known as Corporate Governance Scorecard. Philip Armstrong, Senior Advisor Corporate Governance, IFC, argued that the adherence to scorecard mechanism should act as motivating factor for the organizations (IFC, 2014). In August 2003, Bangladesh Enterprise Institute (BEI) invited a number of prominent individuals from the private sector, the government, Non-Government Organizations (NGOs) and other relevant bodies to begin the process of formulating a Code of Corporate Governance (CCG) for Bangladesh. The Code is organized into principles and guidelines. Organizations can start on the path to better corporate governance, first, by acknowledging the principles of corporate governance and, then, by incorporating them through their own initial implementation strategies (BEI, 2004). CCG provides a standard or branch mark, which is useful to measure financial institutions' performance with best corporate governance practices. Practically, it was first introduced in 2004 (BEI, 2004).

A Company Governance Score (CGS) reflects Standard \& Poor's assessment of an individual company's corporate governance practices and policies. This focuses on the internal governance structure and processes at an individual company. For purposes of the CGS, corporate governance encompasses the interactions between a company's management, its board of directors, shareholders and other financial stakeholders (McGraw-Hill Companies Inc., 2002). According to IFC (2014), "at the 
company level, these goals begin with providing companies with a powerful analytical tool. Scorecards are a useful basis for companies to start an analysis of their governance practices. Scorecards help to identify shortcomings against locally defined standards and/or generally accepted international standards of good practice. The findings of a scorecard can, in turn, be used to help the company to develop a corporate governance improvement plan. The ultimate outcome should be better operational performance and lower risk as a result of better governance practices". Moreover, codes of good corporate governance present a comprehensive set of norms on the role and composition of the board of directors, relationships with shareholders and top management, auditing and information disclosure, as well as the selection, remuneration and dismissal of directors and top managers. The codes serve to improve the overall corporate governance of corporations, especially when legal environments fail to ensure adequate protection of shareholders' rights (Abdel Shahid, S., 2001). There are many potential users of scorecards, such as companies, regulators, stock exchanges, institutes of directors, investors, students, researchers and development finance institutions. Each user has different purpose to use it and fulfill their needs.

Different prior studies indicate that besides corporate governance, there are some other bank specific factors and some macroeconomic factors affecting bank performance as well. Mainly these factors include the level of credit risk, bank's size, bank's efficiency and macroeconomic factors such as GDP, inflation rate, interest rate. Alshatti (2015) investigated that "credit risk is one of the most significant risks that banks face, considering that granting credit is one of the main sources of income in commercial banks. Therefore, the management of the risk related to that credit affects the profitability of the banks ( $\mathrm{Li}$ and Zou, 2014). Aruwa and Musa (2012) investigated the effects of the credit risk, and other risk components on the banks' financial performance. They found a strong relationship between risk components and the banks' financial performance. Boahene, Dasah and Agyei (2012) examined the relationship between credit risk and banks' profitability. They found a positive relationship between credit risk and bank profitability. Though Kithinji (2010) indicated that the larger part of the banks' profits was influenced by other variables other than credit and nonperforming loans". Uchida et al. (2012) found in their significance in investors' perception regarding corporate governance and equity return.

Gakure et al. (2012) investigated the effect of credit risk management techniques on the banks' performance of unsecured loans. They concluded that financial risk in a banking organization might result in imposition of constraints on bank's ability to meet its business objectives. According to the results of a survey made to bank senior managers, the three risk factors that most contributed to the financial crisis were inappropriate risk governance, weak risk culture, and ineffective incentive and remuneration policies (Hashagen, Harman, Conover \& Sharma, 2009). Many argue that effective management of credit risk is inextricably linked to the development of banking technology, which will enable to increase the speed of decision making and simultaneously reduce the cost of controlling credit risk. This requires a complete base of partners and contractors (Lapteva, 2009). On a different note, Hughes \& Mester (2008) found that banks' ability to ameliorate informational asymmetries between borrowers and lenders and their ability to manage risks are the essence of bank production. They further implied that these abilities are integral components of bank output and influence the managerial incentives to produce financial services prudently and efficiently.

Andrieș, Căpraru, Mutu (2016) investigated that "the link between corporate governance and bank efficiency has been analyzed by very few studies with inconclusive results. $\mathrm{Pi}$ and Timme (1993) for the United States, Choi and Hasan (2005) for Korea and Tanna et al. (2011) for the UK banking sector examined the link between board structure and efficiency. The relationship between better governance and efficiency was assessed for US and other international samples by Pi and Timme (1993), Mester (1997), Amess and Drake (2003), Berger and Isik and Hassan (2003)". In any case, in this study, efficiency of banks is measured by cost to income ratio, where operating expense is divided by operating income. This ratio is important for determining the profitability of a bank. It can show how efficiently the bank is doing its operations.

Boyd and Runkle (1993) found a negative relationship between size and bank performance. This means that large sized banks generate lower level of profits than smaller ones. The negative relationship may happen as large banks may have management issues. Large banks may have an aggressive growth strategy which is obtained at the expense of margins and profitability. Tarawneh (2006) described that larger banks do not always have better financial performance. But most studies suggested that there is a significant relationship between bank efficiency and bank performance. On the other hand, Onuonga (2014), Sinkey (1992) and Staikouras and Wood (2003) found mixed results. Sinkey's (1992) results indicate that size affects negatively for big firms and positively for smaller banks. Some studies later found that medium banks earn the highest profits followed by smaller ones. 
While measuring performance of banks in terms of intrinsic factors of the sector, it is often suggested that macroeconomic variables be incorporated within the model. It is argued that as financial sector's impact is huge for economic development, macroeconomic variables contribution cannot be ignored while measuring any factor's influence on the performance of the financial institutions. This point can be judged based on existing research outcomes, such as Ghazali (2008) considered six years data of 60 Islamic banks operating in 18 countries. Results ascertain that GDP and inflation positively influence the revenue of banks. Goddard, Molyneux and Wilson (2004) estimated the profitability of 583 European Union domestic banks where cross sectional regression showed a significant positive effect of GDP on profits. Sufian and Habibullah (2010) stated that favorable conditions in an economy will positively impact the level of financial transactions, and well managed banks will earn from loans and sale of securities. In contrast, some also found negative relationship between GDP and banks profitability. Scott and Arias (2011) studied performance of five largest banks in United States and they found that GDP did not directly affect the profit level of US banking sector. Sufian (2011) also found negative impact of GDP on Return on Assets (ROA), but positive impact with inflation. With similar vein, Khrawish (2011) have done a research to identify the effect of macroeconomics on the listed banks of Jordanian banks and he found a negative impact of GDP and inflation with ROA.

Haron and Azmi (2004) statistically proved that there is a direct relationship of inflation rate and indirect relationship of real interest rate on ROA. Athanasoglou et al. (2006) examined South-Eastern European banks' performance and the result shows high earnings during peak inflation periods and no noticeable effect of GDP. Davydenko (2011) showed that both GDP and inflation have a positive relationship with ROA of Ukrainian banks. Aburime (2008) examined on profitability of Nigerian banks and concluded that both real interest rate and inflation have a considerable link with ROA and positively affect bank profitability. Moreover, Sayilgan and Yildirim (2009) investigated the performance of the banks of Turkey and found that the profitability of the banking sector is increased along with declining inflation rate. Samuelson (1945) found a positive of banks' profitability to rising interest rates. Samuelson Paul A. (1945) showed that when interest rate increases, it actually effect to borrowers, but it does not affect banks' performance. Here, it is explained that borrowers face the impact of higher interest rate but banks profitability is not affected as when interest rate increases, bank charges more from borrower than they pay to the depositors of the banks so that both the depositor and the borrower have to tolerate this impact.
It is worth mentioning Boyd et al.'s (2001) research findings where they presented the summary of the impact of inflation on the performance of the financial/banking sector as follows:

- Higher inflation rate is linked with higher inconsistency in interest margin and stock return.

- In highly inflated economy, there is less long run financial activity, because intermediaries will do less lending and capital investment also less effective.

- If inflation surpasses to a critical level, then, incremental increase in the long run rate of inflation has less impact on banking sector activity.

\section{Methodology and data analysis}

In this study, apart from the corporate governance factor, some other factors that have significant impact on performance of the banks are also explored. Bikker and Bos (2008) stated that performance of banks can be expressed in terms of competition, concentration, efficiency, productivity and profitability. Here, the bank specific variables such as Corporate Governance Score, Size, Risk, Efficiency and external variables such as GDP, Inflation Rate, and Real Interest Rate are considered as predictors. On the other hand, ROA considered as proxy for profitability of the banks.

3.1. Dependent variable: ROA. Return on assets (ROA) is an indicator of how profitable a company is relative to its total assets. ROA gives an idea as to how efficient management is at using its assets to generate earnings (Investopedia, 2003). ROA is calculated by dividing after tax net income by total asset or average total assets of a company. ROA shows us what earnings were generated from invested capital in a company.

\subsection{Independent Variables.}

3.2.1. Corporate governance score. According to IFC (2014), "a scorecard is a quantitative tool to measure the level of observance of a code/or a standard of corporate governance. Scorecards compare governance practices to a benchmark. Typically the benchmark is a national code of corporate governance or an international code or standard. Scorecards are not used principally to measure regulatory compliance. Rather, scorecards measure the observance with a voluntary code of best practice. Scorecards are used to assess a company's governance practices, show progress over time, and compare different companies and even groups of companies within or across countries".

It can measure the quality of governance practices in companies. It can show us whether the companies properly follow the recommended codes. It can be used to compare practices between companies and also between countries. The total score achieved by each of the banks has been used as the measure of bank com- 
pliance with the CCG (Islam, Sathye \& Hu, 2005). Here in this study, score is the main independent variable of whose influence over dependent variable (ROA) is measured. It is hoped a have a positive relationship between them could be found. According to the information in annual reports of banks, there are 99 elements of corporate governance. If any element is complied by a bank, it would score 4 and if not, then, 0 . Thus, the following hypothesis is proposed:

$\mathrm{H}_{1}$ : There is a significant (positive) relation existing between CCG and ROA.

3.2.2. Size of bank. In this study total assets of the banks are used as a proxy for bank size like most finance literature. Generally it is expected that the effect of bank size on profitability is positive. Smirlock (1985) find a positive and significant relationship between size and bank profitability.

However, banks with higher total asset may do not perform well financially. Moreover, size alone may not affect bank performance positively. Different studies have found a positive, some have found negative and also some have a non-significant relationship between banks performance and size of the bank. Thus, the study hypothesizes that:

$\mathrm{H}_{2}$ : There is a significant (positive or negative) relation existing between size and ROA.

3.2.3. Risk. Risk is the position where the actual return of an investment is different than expected return. It means the possibility of losing the original investment and the amount of interests that may earn on it. Banks face different types of risks. Credit risk is one of the most important risks faced by banks. Prior studies founds there is a strong relationship between risk and the performance of banks and it is also usual to notice that too much risk exposure deters profits of banks. Natural logarithm of total provision for bad debt was taken to measure risk. Thus, the study hypothesizes that:

$\mathrm{H}_{3}$ : There is a significant (negative) relation existing between Risk and ROA.

3.2.4. Efficiency. The term "efficiency" is one of the key concepts for financial institutions. It has been extensively studied due to its importance. Operating (productive) efficiency denotes whether a firm is cost minimizing (consuming less inputs for the same level of outputs) or profit maximizing (producing more outputs for the same amount of inputs) (Beccalli et al., 2006). Thus, there are two types of technical efficiency based on the orientation: input-oriented and output oriented (Laeven, 1999).

Hays, De Lurgio, Gilbert (2009) investigated that "the efficiency ratio is calculated by dividing overhead expenses by the sum of net interest income and non-interest or fee income. It is a measure of how effective a bank is in using overhead expenses including salaries and benefit costs and occupancy expenses, as well as other operating expenses in generating revenues. Other things being equal, a decrease in the efficiency ratio is viewed as positive, while a rising efficiency ratio is generally undesirable. The efficiency ratio can rise temporarily when a bank expands facilities". Thus, the study hypothesizes that:

$\mathrm{H}_{4}$ : There is a significant (negative) relation existing between efficiency and ROA.

3.3. Macroeconomic variables. Along with channeling funds efficiently, Banks provide a bundle of different services and, thus, considered as the most important financial intermediaries in the economies. Banks play a vital role in many operations in the economies. The efficiency of the performance of these banks can also affect economic growth. On the other hand, many economic factors can affect banks' profitability. Here, three important determinants are taken to identify their impact on banks performance: GDP, inflation, and real interest rate. These determinants are reflecting economic environment that affects the profitability of banks.

3.3.1. GDP. GDP basically shows the monetary value of all goods and services produced within a country and within a specific period of time. In a country, GDP measures the total economic activates and it may affect the performance of banks. Alpera \& Anbar (2011) mentioned that "It is expected to have an impact on numerous factors related to the demand and supply for banks deposits and loans".

According to the literature on the association between economic growth and financial sector profitability, GDP growth is expected to have a positive relation on bank profitability (Bikker and $\mathrm{Hu}, 2002$ ). Hence, we expect to have a positive relationship between them. So, we propose that:

$\mathrm{H}_{5}$ : There is a significant (positive) relation existing between GDP and ROA.

3.3.2. Inflation rate. Inflation is the rate at which the price level of goods and services increases and it decreases the purchasing power of people. Inflation rate has significant effect on bank performance, but the relationship between them can be positive or negative. Perry (1992) stated that "The relationship between the inflation and profitability may have a positive or negative effect on profitability depending on whether it is anticipated or unanticipated". If inflation rate is anticipated, banks can adjust interest rate so that they can increase the revenue than the expense. On the other hand, if it is not anticipated, banks cannot make correct adjustment of interest rate and the expense will increase than the revenue. Thus, the study hypothesizes that: 
$\mathrm{H}_{6}$ : There is a significant (positive or negative) relation existing between inflation rate and ROA.

3.3.3. Real interest rate. Interest rate plays an important role in our economy. A real interest is adjusted to remove the effect of inflation to show the real cost of borrowing and real interest income to the lender. It is calculated by Fisher equation, which is deducting inflation from nominal interest rate. The interest rate has significant impact on banks performance. Particularly, for developing counties, it is found that the real interest rate has a positive relation to profitability of banks (Borio et. al., 2015). Thus, the study hypothesizes that:

$\mathrm{H}_{7}$ : There is a significant (positive) relation existing between inflation rate and ROA.

Table 1. Variables and respective formulas

\begin{tabular}{|l|l|}
\hline \multicolumn{1}{|c|}{ Variables } & \multicolumn{1}{c|}{ Formulas } \\
\hline Return on Asset & Net Income/ Total Asset \\
\hline Corporate Govt. Score (CCG) & $\begin{array}{l}\text { If the Corporate governance's element is } \\
\text { complied, it scored 4 and if not, then, 0. }\end{array}$ \\
\hline Size & Natural Log of Total Asset \\
\hline Risk & Natural Log of provision for bad debt. \\
\hline Efficiency & Operating income/ Operating expense \\
\hline
\end{tabular}

3.4. Research model. The model and approach used in this study was found in established existing literature:

$R O A=f(C C G$, Size, Risk, Efficiency $)$.

Three basic core panel OLS regression equation model were, then, proposed:

ROA $=\beta_{0}+\beta_{1}$ Score $+\beta_{2}$ Size $+\beta_{3}$ Risk $+\beta_{4}$ Efficiency + $+\beta_{5} \mathrm{GDP}+\beta_{6}$ Inflation $+\beta_{7}$ Interest rate Model 1

ROA $=\beta_{0}+\beta_{1}$ Score $+\beta_{2}$ Size $+\beta_{3}$ Risk $+\beta_{4}$ Inflation + $+\beta_{5}$ Interest rate Model 2

$\mathrm{ROA}=\beta_{0}+\beta_{1}$ Score $+\beta_{2}$ Risk $+\beta_{3}$ Efficiency + $+\beta_{4}$ Inflation $+\beta_{5}$ Interest rate
3.5. Research design. The study's main purpose was to identify impact of corporate governance on the performance of private commercial banks of Bangladesh. This is a cross sectional study, because this research is done based on 4 years of annual reports of 29 private commercial banks of Bangladesh without comparing results over longer time horizon.

3.6. Data collection \& sampling. This research has been prepared based on secondary data collected from annual reports of private commercial banks of Bangladesh. Banking sector of Bangladesh consists of 64 banks where state-owned banks are 4 , private commercial banks are 32, Islamic commercial banks are 8; foreign banks are 9 and specialized banks are 11. For doing the research, private commercial banks are taken as a sample unit to evaluate the impact of corporate governance on financial performance of banks in Bangladesh. Only Dhaka Stock Exchange (DSE) listed commercial banks were selected. Besides, in order to maintain the balanced panel data, data availability (4 years data: 2011 to 2014) was other selection criteria. After considering both the factors, 29 commercial banks were included in the study. Once the sample units were confirmed, the annual reports of these banks were collected from DSE. The calculation of some ratio is done through the data obtained from consolidated balance sheet, income statement and section of corporate governance.

3.7. Data analysis. Multiple regression analysis has been done to test the relationship between banks' performance measured by ROA and corporate governance score, size, risk, efficiency and some macro-economic variables. This analysis is done by using EViews 8 software to run regression equation calculation, correlations and descriptive statistics.

Table 2. Descriptive statistics of the variables

\begin{tabular}{|c|c|c|c|c|c|c|}
\hline & Mean & Median & Maximum & Minimum & Std. Dev. & No. of observation \\
\hline ROA & 0.011267 & 0.010161 & 0.217471 & -0.099702 & 0.026736 & 116 \\
\hline Score & 281.1379 & 334 & 396 & 0 & 106.6357 & 116 \\
\hline Size & 25.62433 & 25.67258 & 27.20396 & 22.90881 & 0.627941 & 116 \\
\hline Risk & 20.92539 & 20.86691 & 24.79163 & 18.0429 & 1.003313 & 116 \\
\hline Efficiency & 0.476556 & 0.43545 & 1.801975 & 0.054528 & 0.209013 & 116 \\
\hline GDP & 30.04427 & 30.05119 & 30.22901 & 29.84568 & 0.143638 & 116 \\
\hline Inflation & 0.0787 & 0.07275 & 0.107 & 0.0623 & 0.017064 & 116 \\
\hline Interest rate & 0.0545 & 0.052 & 0.069 & 0.045 & 0.008997 & 116 \\
\hline
\end{tabular}

3.8. Descriptive statistics of the variables. Table 2 represents the descriptive statistics of the research. In this study, the sample size is 29 and number of years is 4 (2011 to 2014), so total observation number is 116. Here, descriptive statistics show that the commercial banks of Bangladesh are fairly compliant with the requirements having an average of
281.14 Corporate Governance Score; though standard deviation is very high, 106.63 .

3.9. Regression analysis. In Table 3 , the following data got from the output, as ROA is regressed against CCG, size, risk, efficiency, GDP, inflation, and interest rate in three different models. 
Table 3. Regression analysis

\begin{tabular}{|c|c|c|c|}
\hline \multirow{2}{*}{ Intercept } & Model 1 & Model 2 & Model 3 \\
\hline & -1.89490 & -0.17646 & 0.07201 \\
\hline Score (CCG) & $\begin{array}{l}1.08 \mathrm{E}-05 \\
(0.7572)\end{array}$ & $\begin{array}{c}1.98 \mathrm{E}-05 \\
(0.5906)\end{array}$ & $\begin{array}{c}2.04 \mathrm{E}-05 \\
(0.548)\end{array}$ \\
\hline Size & $\begin{array}{r}-0.00465 \\
(0.3931)\end{array}$ & $\begin{array}{l}0.009165 \\
(0.0548)^{*}\end{array}$ & - \\
\hline Risk & $\begin{array}{r}-0.00240 \\
(0.4312)\end{array}$ & $\begin{array}{r}-0.00363 \\
(0.2634)\end{array}$ & $\begin{array}{c}-0.0033 \\
(0.217)\end{array}$ \\
\hline Efficiency & $\begin{array}{l}-0.06245 \\
(0.0000)^{*}\end{array}$ & - & $\begin{array}{l}-0.05365 \\
(0.0000)^{*}\end{array}$ \\
\hline GDP & $\begin{array}{c}0.069646 \\
(0.3043)\end{array}$ & - & - \\
\hline Inflation rate & $\begin{array}{c}0.485319 \\
(0.1637)\end{array}$ & $\begin{array}{c}0.304814 \\
(0.1784)\end{array}$ & $\begin{array}{l}0.21801 \\
(0.2996)\end{array}$ \\
\hline Interest rate & $\begin{array}{r}-0.52571 \\
(0.5104)\end{array}$ & $\begin{array}{r}-0.01167 \\
(0.9675)\end{array}$ & $\begin{array}{l}0.20198 \\
(0.4504)\end{array}$ \\
\hline $\mathrm{R}^{2}$ & 0.201083 & 0.055689 & 0.18802 \\
\hline Adjusted $\mathrm{R}^{2}$ & 0.149301 & 0.012766 & 0.15111 \\
\hline F-statistic & 3.883288 & 1.297414 & 5.09427 \\
\hline$P$-value & $0.000826^{*}$ & 0.270267 & $0.00031^{*}$ \\
\hline
\end{tabular}

The p-values are in parentheses with * denoting significance at $10 \%$ level.

According to the result of model 1 , here, CCG shows a positive relation to ROA though the relation is not statistically significant at $10 \%$ significance level. Out of all the variables, only efficiency shows a statistical significant relation to ROA though a lower p-value $(<\alpha=10 \%)$ proves the model to be a good fit one. The equation also has a $\mathrm{R}^{2}$ of roughly $20 \%$ meaning that the variation of the ROA can be explained by all the dependent variables together. Finally, for model 1, though not statistically significant, the GDP and inflation show a positive relationship with ROA, whereas, size, risk and interest rate show negative relationship with ROA. These findings are in congruence with findings of existing researches in different context, as discussed in the literature review, e.g., Boyd and Runkle (1993), Tarawneh, (2006), Ramlall (2009), KPMG (2010), Davydenko (2011).

In case of model 2 , the above scenario does not change much, rather deteriorates. In model 2 , the size can only be considered as statistically significant in determining value of ROA, whereas the $\mathrm{R}^{2}$ decreases slightly compare to model 1 . However, corporate governance factor does show a positive relation to ROA.

Finally, in the third model, overall findings resemble that of the model 1 . Such as, $\mathrm{R}^{2}$ is 0.18802 so that all the independent variables explain the dependent variable by $18.802 \%$. Here $p$-value is 0.000307 that is lower than significant level which is .10 . So, the model is good fit one. In summary, it can be said that among the proposed hypotheses, only hypothesis 2 and hypothesis 4 are accepted. In addition, it is noticeable that, within the three models, corporate governance consistently shows positive relation to ROA though not significant.

\section{Conclusion}

Private commercial banks play an important role in our economy. Sound corporate governance should ensure better banks performance. Based on some prior studies and also in this study, it is found that corporate governance has a positive relationship with banks performance though the relationship is not significant. Only few years ago corporate governance practice is embraced by all the private commercial banks in Bangladesh. But after introduction of the CCG, the practices of corporate governance have been significantly improved. The aim of this study was to investigate whether compliance to corporate governance codes do really matter for the commercial banks of the country. Hence, three models used to identify the influence. All the models show that the corporate governance has positive relation to the performance of commercial banks in Bangladesh, however, none of them are statistically significant. Actually, a well managed bank must perform better than that of others; otherwise compliance to corporate governance codes would lose its essence. Thus, on the one hand, the result indicates probable inherent management issues of the banks and/or the market. Else, it can be argued that may not be in the short run, reflection of corporate governance's impact on performance may get its strong foothold in the days to come. Nonetheless, findings of the study will be helpful for future researches, policy makers and bank managements. Least, as corporate governance has a positive relationship with banks performance, it can be inferred from the findings that sound corporate governance is needed for a stable, well-functioned and well performed banking system in Bangladesh. 


\section{References}

1. Abdel Shahid, S. (2001) Corporate Governance is a Global Pursuit: What Could Be Done in Egypt? SSRN Electronic Journal. Available at: http://dx.doi.org/10.2139/ssrn.286875.

2. Aburime, T.U. (2008). Determinants of bank profitability: macroeconomic evidence from Nigeria. Retrieved from: http://papers.ssrn.com/sol3/papers.cfm?abstract_id=1231064.

3. Ahmed, S.U. and Uchida S. (2009). Benchmarking the State of Corporate Governance in Bangladesh, KEIEI TO KEIZAI, Vol. 89, No. 3, December 2009.

4. Ajanthan, A., Balaputhiran, S. \& Balasundaram, N. (2013). Corporate Governance and Banking Performance: A Comparative Study between Private and State Banking Sector in Sri Lanka. European Journal of Business and Management, 5 (No. 20), p. 92.

5. Alpera, D. \& Anbar, A. (2011). Bank Specific and Macroeconomic Determinants of Commercial Bank Profitability: Empirical Evidence from Turkey, Business and Economics Research Journal, 2 (2).

6. Alshatti, Ali Sulieman. (2015) The effect of credit risk management on financial performance of the Jordanian commercial banks, Investment Management and Financial Innovations, Volume 12, Issue 1, pp. 338-345.

7. Amess, Kevin and Leigh, Drake. (2003). Executive Remuneration and Firm Performance: Evidence from a Panel of Mutual Organizations. Discussion Papers in Economics, No. 03/13, University of Leicester.

8. Andrieș, Alin Marius, Căpraru, Bogdan, Mutu, Simona. (2016). Corporate Governance and Efficiency in Banking: Evidence from Emerging Economies. Available at: https://ermas2016.uvt.ro/Presenters/14_Simona_Mutu.pdf.

9. Aruwa, S.A. and Musa, O.A. (2014). Risk components and the financial performance of deposit money in Nigeria, International Journal of Social Sciences and Entrepreneurship, 1 (11), pp. 1-8. Available at: http://www.ijsse.org.

10. Athanasoglou, P.P., Delis, M.D. \& Staikouras, C.K. (2006). Determinants of Bank Profitability in the South Eastern European Region. Munich Personal RePEc Archive.

11. Bangladesh Bureau of Statistics. (2016). Bbs.gov.bd. Retrieved 5 May 2016. Available at: http://www.bbs.gov.bd/PageWebMenuContent.aspx?MenuKey=363.

12. Basuony, M.A., Mohamed E.K.A. and Al-Baidhani, A.M. (2014). The Effect of Corporate Governance on Bank Financial Performance: Evidence from the Arabian Peninsula, Corporate Ownership \& Control, 11 (2), pp. 178-191.

13. BB. (2016). Website of Bangladesh Bank.

14. BCBS. (2006, February). Enhancing corporate governance for banking organizations, Basel Committee on Banking Supervision, BIS, Basel.

15. Beccalli, E., Casu, B., Girardone, C. (2006). Efficiency and Stock Performance in European Banking, Journal of Business Finance \& Accounting, 33 (1-2), pp. 245-262.

16. BEI. (2004). The CCG for Bangladesh: principle and guidelines for best practices in the private sector, financial institutions, state-owned enterprises and non-governmental organizations, Bangladesh Enterprise Institute, Dhaka.

17. Bikker, J.A., Bos, W.B. (2008). Bank Performance: A Theoretical and Empirical Framework for the Analysis of Profitability, Competition nd Efficiency, NY: Routledge.

18. Boahene, S.H., Dasah, J. and Agyei, S.K. (2012). Credit Risk and Profitability of Selected Banks in Ghana, Research Journal of Finance and Accounting, 3 (7), pp. 6-15.

19. Borio, C., Gambacorta, L. and Hofmann, B. (2015). The Influence of Monetary Policy on Bank Profitability, Bank for International Settlements.

20. Boyd, J., Levine, R. et al. (2001). The Impact of Inflation on Financial Sector Performance, Journal of Monetary Economics, 47, pp. 221-248.

21. Brigham, E.F. and Ehrhardt, M.C. (2005). Financial Management: Theory and Practice. United States of America: South-Western, Thomson Corporation.

22. Cadbury Committee. (1992). Cadbury Reports, London Stock Exchange, London.

23. Choi, S., Hasan, I. (2005). Ownership, governance, and bank performance: Korean experience, Financial Markets, Institutions and Instruments, 14 (4), pp. 215-241, 20, 21.

24. Davydenko, A. (2011). Determinants of Bank Profitability in Ukraine, Undergraduate Economic Review, 7(1). Retrieved from http://digitalcommons.iwu.edu/uer/vol7/iss1/2.

25. Fan, L. and Yijun, Z. (2014). The Impact of credit risk management on profitability of commercial banks: A study of Europe, Umea School of Business and Economics: Available at: http://www.diva-portal.org.

26. Farooque, O.A., Zijl, T.V., Dunstan, K. \& Karim, A.W. (2007).Corporate governance in Bangladesh: Link between ownership and financial performance, Corporate Governance: An International Review, 15, pp. 1453-1468.

27. Gakure, R.W., Ngugi, J.K., Ndwiga, P.M. and Waithaka, S.M. (2012). Effect of Credit Risk Management Techniques on the Performance of Unsecured Bank Loans Employed Commercial Banks in Kenya, International Journal of Business and Social Research, 2 (4), pp. 221-236. Available at: http://thejournalofbusiness.org.

28. Ghazali, M.B. (2008). The bank-specific and macroeconomic determinants of Islamic bank profitability: some international evidence. Dissertation (M.B.A.), University of Malaya, Faculty of Business and Accountancy. Retrieved from: http://dspace.fsktm.um.edu.my/handle/1812/752.

29. Goddard, J., Molyneux, P. \& Wilson, J.O. (2004). Dynamics of Growth and Profitability in Banking, Journal of Money, Credit and Banking, 36 (6), pp. 1069-1090. 
30. Haron, S. \& Azmi, W.N. (2004). Profitability determinants of Islamic banks: a cointergration approach. Islamic Banking Conference, Union Arab Bank. Beirut, Lebnon: Kuala Lampur Business School. Retrieved from: http://klbs.com.my/v1/wpcontent/uploads/2012/04/004-Profitability-of-Islamicbank.

31. Hashagen, J., Harman, N., Conover, M. \& Sharma, J. (2009). Risk Management in Banking: Beyond the Credit Crisis, Journal of Structured Finance, vol. 15 (1), pp. 92-103.

32. Hays, Fred H., De Lurgio, Stephen A., Gilbert, Arthur H. (2009). Efficiency Ratios and Community Bank Performance Journal of Finance and Accountancy, Vol. 1, p.1-15. Available at: http://www.aabri.com/manuscripts/09227.pdf.

33. Herring, R.J. (1999). Credit risk and financial instability, Oxford Review of Economic Policy, 15, pp. 63-79.

34. Hughes, J. \& Mester. (2008). L. Efficiency in Banking: Theory, Practice, and Evidence, SSRN Electronic Journal. Available at: http://dx.doi.org/10.2139/ssrn.1092220.

35. IFC. (2014). Corporate Governance Scorecards: Assessing and Promoting the Implementation of Codes of Corporate Governance, IFC Corporate Governance Knowledge Tool, International Finance Corporation, World Bank Group.

36. Isik, Ihsan and Hassan, Kabir M. (2003). Efficiency, Ownership and Market Structure, Corporate Control and Governance in the Turkish Banking Industry, Journal of Business Finance and Accounting, 30, pp. 1363-1421.

37. Islam, J., Sathye, M., Hu, H. (2015). Examining the relationship between corporate governance and bank performance in Bangladesh, South African Journal of Business Management, 46 (4).

38. Khrawish, H.A. (2011). Determinants of commercial banks performance: evidence from Jordan, International Research Journal of Finance and Economics, 81, pp. 148-159. Retrieved from: http://www.internationalresearchjournaloffinanceandeconomics.com.

39. Kithinji, A.M. (2010). Credit risk management and profitability of commercial banks in Kenya, Working paper, School of Business, University of Nairobi, Kenya. Available at: http://erepository.uonbi.ac.ke.

40. KPMG. (2010). KPMG Financial Institutions Performance Survey. Sydney: KPMG.

41. Laeven L. (1999). Risk and Efficiency in East Asian Banks. World Bank Policy Research Working Paper No. 2255. [Online] Available at: <http://ssrn.com/abstract=629192>last accessed: February 20, 2008.

42. Lapteva, M.N. (2009). Credit Risk Management in the Bank, Letter from the Bank of Russia 'On typical banking risks'. Available at: http://vestnik.sseu.ru/view_pdf.php?pdf=2224.

43. McGraw-Hill Companies Inc. (2002). Standard \& Poor's Corporate Governance Scores, Journal of standard \& poor's Governance Services, pp. 2-4.

44. Onuonga, S. (2014). The Analysis of Profitability of Kenya`s Top Six Commercial Banks: Internal Factor Analysis, American International Journal of Social Science, Vol. 3, No. 5; October 2014 (5), p. 4.

45. Paul, A. Samuelson. (1945). The effects of interest rate increases on banking system, The American economic review, Vol. 35, No. 1, pp. 16-27.

46. Pound, J. (1995). The Promise of the Governed Corporation, Harvard Business Review, March.

47. Public Accounts and Estimates Committee. (2002). Inquiry into Corporate Governance in the Victorian Public Sector, Issue Paper, Australia.

48. Ramlall, I. (2009). Bank-specific, industry-specific and macroeconomic determinants of profitability in Taiwanese banking.

49. Return on Assets (ROA) Definition | Investopedia. (2003). Investopedia. Retrieved 26 March 2016, Available at: http://www.investopedia.com/terms/r/returnonassets.asp.

50. Samuelson, P.A. (1945). The Effect of Interest Rate Increases on the Banking System, American Economic Review, 305, pp. 16-27.

51. Sayilgan, G. \& Yildirim, O. (2009). Determinants of Profitability in Turkish Banking Sector: 2002-2007, International Research Journal of Finance and Economics, 28, pp. 207-213.

52. Scott, J.W. \& Arias, J.C. (2011). Banking profitability determinants, Business Intelligence Journal, 4 (2), pp. 209-230.

53. Sinkey, J.J. (1992). Commercial bank financial management in the financial services industry, N.Y: Macmillan Publishing Company.

54. Smirlock, M. (1985). Evidence on the (Non) Relationship between concentration and profitability in Banking, Journal of Money Credit and Banking, 17, pp. 69-83.

55. Staikouras, C. \& Wood, G. (2003). The determinants of bank profitability in Europe. Paper presented at the European Applied Business Research conference.

56. Sufian, F. \& Habibullah, M.S. (2010). Assessing the impact of financial crisis on bank Performance, empirical evidence from Indonesia, ASEAN Economic Bulletin, 27, pp. 245-262.

57. Sufian, F. (2011). Profitability ofthe Korean Banking Sector: Panel Evidence on Bank-Specific and Macroeconomic Determinants, Journal of Economics and Management, 7 (1), pp. 43-72.

58. Tarawneh, M. (2006). A comparison of Financial Performance in the Banking Sector: Some Evidence from Omani Commercial Banks, International Research Journal of Finance and Economics, Issue 3.

59. Uchida, S., Ahmed, S.U. and Abed, A.A. (2011). Corporate Governance and Firm Performance in the Financial Sector, KEIEI TO KEIZAI, Vol. 52.

60. Uchida, S., Ahmed, S.U. and Islam, M.Z. (2012). Corporate Governance and Equity Returns, KEIEI TO KEIZAI, Vol. 91, No. 4, March 2012.

61. Wheelen, T.L. \& Hunger, J. (2006). Strategic Management and Business Policy. United States of America: Pearson Prentice Hall. Available at: http://www.kvimis.co.in/sites/kvimis.co.in/files/ebook_attachments/Thomas \%20L.\%20Wheelen,\%20Strategic\%20Management.pdf. 